\title{
Clinical Investigations
}

\section{Effects of Imidapril Therapy on Endogenous Fibrinolysis in Patients with Recent Myocardial Infarction}

\author{
Hirofumi Soejima, M.D., Hisao Ogawa, M.D., Hirofumi Yasue, M.D., Hisakazu Suefujl, M.D., Koichi Kaikita, M.D., \\ KOICHI NISHIYAMA, M.D. \\ Division of Cardiology, Kumamoto University School of Medicine, Kumamoto, Japan
}

\section{Summary}

Background: Treatment with an angiotensin-converting enzyme (ACE) inhibitor in patients with myocardial infarction has been shown to modify endogenous fibrinolysis.

Hypothesis: We investigated the effects of the ACE inhibitor imidapril on endogenous fibrinolysis in association with the serum ACE activity.

Methods: In a randomized, double-blind, placebo-controlled study beginning 4 weeks after uncomplicated myocardial infarction, 15 patients received imidapril ( $5 \mathrm{mg}$ daily) (imidapril group) and another 15 received placebo therapy (placebo group) for 4 weeks. Blood sampling was performed before the start of administration and on Days 3, 7, and 28 after the start of administration. Serum ACE activity and plasma tibrinolytic variables [plasminogen activator inhibitor (PAI) activity, plasminogen activator inhibitor type 1 (PAI-1) antigen level, and tissue type plasminogen activator (TPA) antigen level] were measured.

Results: There was no difference between the imidapril and placebo groups in serum ACE activity or plasma fibrinolytic variables before administration. Serum ACE activity decreased significantly on Days 3, 7, and 28 in the imidapril

This study was supported in part by a Grant-in-Aid for Scientific Research, C07670794, from the Ministry of Education, the Research Grant for Cardiovascular Diseases (6A-1 and 7A-3) from the Ministry of Health and Welfare, and a research grant from the Smoking Foundation, Tokyo, Japan.

Address for reprints:

Hisao Ogawa, M.D.

Division of Cardiology

Kumamoto University School of Medicine

1-1-1 Honjo

Kumamoto City 860, Japan

Received: September 1, 1996

Accepted with revision: January 23, 1997 group. The decrease of PAI activity and PAI- 1 antigen levels was significantly less on Days 7 and 28 , but not on Day 3 . The TPA antigen level in the imidapril group was unchanged. None of the parameters in the placebo group was changed.

Conclusion: The ACE inhibitor imidapril modified fibrinolysis, but the effects occurred after the inhibition of serum ACE activity.

Key words: angiotensin-converting enzyme inhibitor, angiotensin-converting enzyme activity, plasminogen activator inhibitor activity and antigen, tissue type plasminogen activator antigen

\section{Introduction}

To elucidate the effects of angiotensin-converting enzyme (ACE) inhibitors on endogenous fibrinolysis, we investigated the effects in association with serum ACE activity.

The central component of the fibrinolytic system is plasmin, which degrades fibrin or thrombus and which is converted from plasminogen by tissue type plasminogen activator (TPA). ${ }^{1}$ However, TPA in plasma is rapidly inhibited by plasminogen activator inhibitor (PAI). ${ }^{2}$ Thus, the net fibrinolytic activity in plasma reflects the balance between PAI and TPA. TPA promotes fibrinolysis, ${ }^{1}$ whereas its specific inhibitor, PAI, rapidly inhibits it by forming a complex with TPA. PAI activity, mainly as PAI- 1 activity, is a major determinant of overall fibrinolytic activity. 1,3 Large-scale, placebo-controlled studies have shown that the administration of ACE inhibitors in patients after myocardial infarction (MI) reduces the incidence of recurrent coronary thrombosis, 4,5 We and others have reported that an impaired endogenous fibrinolytic system is associated with an increased risk of intravascular thrombosis. ${ }^{6-8}$ Decreased level of plasminogen activator inhibitor has been shown to be associated with a reduced incidence of reinfarction. ${ }^{9,10}$

On the other hand, angiotensin II is known to increase PAI1. ${ }^{11}$ Furthermore, treatment with an ACE inhibitor has been shown to decrease elevated plasma PAI-1 activity. ${ }^{12}$ However, the effects of ACE inhibitors have been studied only at a 
chronic phase and the relationship with ACE activity is not clear. Therefore, we compared the changes in serum ACE activity, plasma PAI activity, PAI-1 antigen levels, and TPA antigen levels on the day before the start of administration and on Days 3, 7, and 28 after the start of administration between the patients who received imidapril (Tanatril $1^{\oplus}$, Tanabe Seiyaku Co. Ltd., Osaka, Japan) and those who received placebo. Imidapril is a prodrug type of ACE inhibitor whose pharmacologic effects are derived from its active metabolite (imidaprilat). Imidaprilat is almost as effective as enalaprilat and about twice as effective as captopril in inhibiting ACE activity. ${ }^{13}$

\section{Methods}

\section{Study Population}

Thirty patients who had experienced first MI were recruited 4 weeks after the onset of MI. In addition to a typical history, the patients showed pathologic $Q$ waves on the electrocardiogram (ECG) or had a peak creatine kinase level at least twice the upper limit of the normal range. All patients took calcium antagonists, long-acting nitrates, and $81 \mathrm{mg}$ of aspirin daily from the time of admission to hospital, and this drug protocol remained unchanged during the study period. None of the patients had previously taken an ACE inhibitor. At the time of recruitment, a full clinical assessment was made and a chest radiograph and symptom-limited treadmill exercise test were performed. No patients had clinical or radiological signs of heart failure or evidence of ischemia or arrhythmia requiring additional therapy. Fifteen patients were randomized to imidapril treatment (imidapril group) and the other 15 to placebo treatment (placebo group).

\section{Study Protocol}

This study was designed as a randomized, double-blind, placebo-controlled trial. Entry into the study was at 4 weeks after the onset of MI to avoid any acute-phase response. Patients received $5 \mathrm{mg}$ of imidapril or a tablet of placebo each morning for 4 weeks. No patients had significant hypotensive response or abnormal electrolytes during this study. Patients fasted from 10:00 P.M. the previous night, took their usual drugs at 7:00 A.M., and attended the outpatient department at 8:00 A.M. on the day before the start of administration, and on Days 3, 7, and 28 after the start of imidapril or placebo administration at 7:00 A.M. ${ }^{14}$ All patients lay recumbent, and a 21 -gauge needle was inserted into an antecubital vein. Then, an initial $3 \mathrm{ml}$ of blood was used for measuring lipid concentrations, and a further $4.5 \mathrm{ml}$ of blood for assay of fibrinolytic variables was drawn into sodium citrate $(0.13 \mathrm{~mol} / \mathrm{l}, \mathrm{pH} 7.5)$. Then another $5 \mathrm{ml}$ of blood for measurement of ACE activity was drawn into a plain glass tube. The samples for assay of fibrinolytic variables were immediately centrifuged at 3,000 $\mathrm{rpm}$ for $10 \mathrm{~min}$ at $4^{\circ} \mathrm{C}$. The samples for lipid concentrations and ACE activity assay were left in room air for $30 \mathrm{~min}$ and centrifuged in the same way. After centrifugation, the samples were immediately stored at $-80^{\circ} \mathrm{C}$ until analysis. The study protocol followed the guidelines of the ethics committee at our institution. Informed consent was obtained from each patient and control subject.

\section{Assays}

Serum ACE activity assay: Serum ACE activity was measured by colorimetry with an ACE color (Fujirebio Inc.. Tokyo) using the substrate (p-hydroxybenzoyl-glycyl-L-histidylL-leucine)..$^{15}$ The results are expressed in IU/. The intra- and interassay coefficients of variation in this kit were 5.8 and $14.3 \%$, respectively. The normal mean \pm standard error of mean (SEM) value for ACE activity measured in our laboratory $(\mathrm{n}=19)$ was $14.5 \pm 0.9 \mathrm{IU} / 1$.

Plasma PAl activity assay: Plasma PAI activity was determined by a chromogenic substrate assay with a Spectrolyse $(\mathrm{PL})$ reagent kit (Biopool, Umeå, Sweden). ${ }^{16}$ The results are expressed in IU $/ \mathrm{ml}$. The intra- and interassay coefficients of variation in this kit were $9.4 \%$ and $11.4 \%$, respectively. The normal mean \pm SEM value for PAI activity measured in our laboratory $(\mathrm{n}=33)$ was $5.2 \pm 0.5 \mathrm{IU} / \mathrm{ml}$.

Plasma PAI-I antigen level assay: Plasma PAI-1 antigen level was determined by a two-site enzyme-linked immunosorbent assay with an TintElize PAI-1 reagent kit (Biopool, Umeå, Sweden). ${ }^{17}$ The results are expressed in ng/ml. The intra- and interassay coefficients of variation in this kit were 5.8 and $8.5 \%$, respectively. The normal mean \pm SEM value for PAI-1 antigen level measured in our laboratory $(n=25)$ was $15.3 \pm 0.9 \mathrm{ng} / \mathrm{ml}$.

Plasma TPA antigen level assay: Plasma TPA antigen level was measured by an enzyme-linked immunosorbent assay with an ASSERACHROM TPA reagent kit (Diagnostica Stago, Inca, Franconville, France). ${ }^{18}$ The results are expressed in $\mathrm{ng} / \mathrm{ml}$. The intra- and interassay coefficients of variation in this kit were 2.4 and $4.7 \%$, respectively. The normal mean \pm SEM value for TPA antigen level measured in our laboratory $(\mathrm{n}=33)$ was $5.6 \pm 0.3 \mathrm{ng} / \mathrm{ml}$.

Lipids: Total plasma cholesterol and triglyceride levels were determined enzymatically and high-density lipoprotein cholesterol levels were determined using magnesium dextran.

\section{Statistical Analyses}

All data are shown as mean \pm SEM. The clinical characteristics were compared between imidapril and placebo groups using the unpaired $t$-test for continuous data and $\chi^{2}$ test for frequency data. The levels of serum ACE activity, plasma PAI activity, PAI-1 antigen, and TPA antigen between the imidapril and placebo groups at baseline were compared using the Mann-Whitney U test. Levels over the time course in the two patient groups were compared by two-way ANOVA with repeated measures. When the difference was significant, the significance level for correlations was given after application of the Bonferroni method for comparison of within group changes, and the Mann-Whitney $U$ test was used for comparison of the group data. Probability levels $<0.05$ were considered significant. 
TABLE I Baseline characteristics in the placebo and imidapril groups (mean \pm SEM)

\begin{tabular}{lcc}
\hline & $\begin{array}{c}\text { Placebo group } \\
(\mathrm{n}=15)\end{array}$ & $\begin{array}{c}\text { Imidapril group } \\
(\mathrm{n}=15)\end{array}$ \\
\hline Age (years) & $68 \pm 2$ & $67 \pm 2$ \\
Men/women (n) & $11 / 4$ & $12 / 3$ \\
Systemic hypertension $(\mathrm{n})$ & 6 & 8 \\
Serum total-cholesterol $(\mathrm{mg} / \mathrm{dl})$ & $180 \pm 7$ & $186 \pm 8$ \\
Serum tryglyceride $(\mathrm{mg} / \mathrm{dl})$ & $139 \pm 20$ & $131 \pm 14$ \\
Serum HDL cholesterol $(\mathrm{mg} / \mathrm{dl})$ & $38 \pm 2$ & $39 \pm 2$ \\
Cigarette smoking $(\mathrm{n})$ & 6 & 5 \\
Diabetes mellitus $(\mathrm{n})$ & 4 & 3 \\
Obesity $(\mathrm{n})$ & 4 & 4 \\
Drugs & & \\
$\quad$ Calcium antagonists $(\mathrm{n})$ & 9 & 8 \\
Long-acting nitrates $(\mathrm{n})$ & 10 & 11 \\
Aspirin $(\mathrm{n})$ & 15 & 15 \\
\hline
\end{tabular}

Abbreviations: $\mathrm{HDL}=$ high-density lipoprotein, $\mathrm{SEM}=$ standard error of mean.

\section{Results}

\section{Baseline Characteristics}

As shown in Table I, there was no significant difference in baseline characteristics between the imidapril and placebo groups as shown in Table 1. There were no significant differences in age, gender, hypertension, obesity, diabetes mellitus, history of smoking, or in the levels of total cholesterol, triglyceride, or high-density lipoprotein cholesterol between the two groups, neither was there a significant difference in medications.

\section{Baseline ACE Activity and Fibrinolytic Variables}

As shown in Table II, there were no differences between the imidapril and placebo groups in the mean values of serum ACE activity, plasma PAI activity, plasma PAI-1 antigen, or plasma TPA antigen on the day before the start of administration.

\section{Serum ACE Activity After Administration}

There was a significant difference in serum ACE activity (mean \pm SEM IU/l) after administration of imidapril: it changed from $14.9 \pm 1.4$ at baseline to $5.1 \pm 0.9$ on Day 3 , to $6.1 \pm 1.2$ on Day 7 , and to $6.2 \pm 1.2$ on Day 28 of administration (p<0.01; Fig. 1). Serum ACE activity in the placebo group was unchanged. The levels on Days 3,7 , and 28 in the imidapril group were significantly lower than those in the placebo group $(\mathrm{p}<0.01)$.

\section{Plasma PAI Activity after Administration}

Plasma PAI activity (mean \pm SEM IU $/ \mathrm{ml}$ ) after administration of imidapril changed from $9.5 \pm 1.0$ at baseline to $7.4 \pm$ 1.1 on Day 3 , to $6.8 \pm 0.9$ on Day 7 , and to $5.3 \pm 1.0$ on Day 28 of administration, with a significant difference on Day 28
TABLE II Fibrinolytic variables and angiotensin-converting enzyme activity at baseline in the placebo and imidapril groups (mean \pm SEM)

\begin{tabular}{lcc}
\hline & $\begin{array}{c}\text { Placebo group } \\
(\mathrm{n}=15)\end{array}$ & $\begin{array}{c}\text { Imidapril group } \\
(\mathrm{n}=1.5)\end{array}$ \\
\hline ACE activity (IU/) & $15.3 \pm 1.1$ & $15.3 \pm 1.1$ \\
PAI activity (IU/ml) & $11.7 \pm 1.0$ & $12.0 \pm 0.9$ \\
PAI-1 antigen level $(\mathrm{ng} / \mathrm{ml})$ & $25.0 \pm 1.4$ & $24.2 \pm 1.5$ \\
TPA antigen level $(\mathrm{ng} / \mathrm{ml})$ & $10.7 \pm 1.0$ & $10.4 \pm 1.0$ \\
\hline
\end{tabular}

Abbreviations: $\mathrm{ACE}=$ angiotension-converting enzyme, $\mathrm{PAI}=$ plasminogen activator inhibitor, PAI-1 = plasminogen activator inhibitor type $1, T P A=$ tissue type plasminogen activator, $\mathrm{SEM}=$ standard error of mean.

( $<<0.01$; Fig. 2). Plasma PAI activity in the placebo group was unchanged. The levels in the imidapril group were significantly lower than those in the placebo group on Day 7 $(\mathrm{p}<0.05)$ and Day $28(\mathrm{p}<0.01)$.

\section{Plasma PAI-1 Antigen Level after Administration}

The plasma PAI-1 antigen level (mean \pm SEM $n g / m l)$ after administration of imidapril changed from $24.2 \pm 1.5$ at baseline to $21.4 \pm 1.8$ on Day 3, to $19.8 \pm 1.5$ on Day 7 , and to 17.3 \pm 1.5 on Day 28 of administration, with a significant difference on Day 28 ( $p<0.01$; Fig. 3). The plasma PAI-1 antigen level in the placebo group was unchanged. The levels in the imidapril group were significantly lower than those in the placebo group on Day $7(p<0.05)$ and on Day $28(p<0.01)$.

\section{Plasma TPA Antigen Level after Administration}

The plasma TPA antigen level (mean \pm SEM $\mathrm{ng} / \mathrm{ml}$ ) did not change significantly after administration of imidapril (Fig. 4). The plasma TPA antigen level in the placebo group was unchanged.

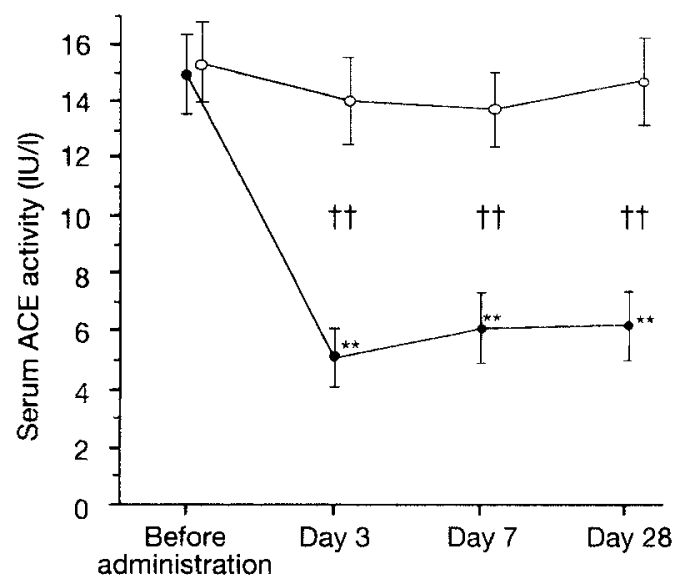

FIG. 1 Serial changes of the serum angiotensin-converting enzyme (ACE) activity in the imidapril and placebo groups. $-=$ Imidapril, $-O=$ placebo. ${ }^{* *} p<0.01$ vs. before administration, $\dagger+=p<0.01$ vs. placebo. 


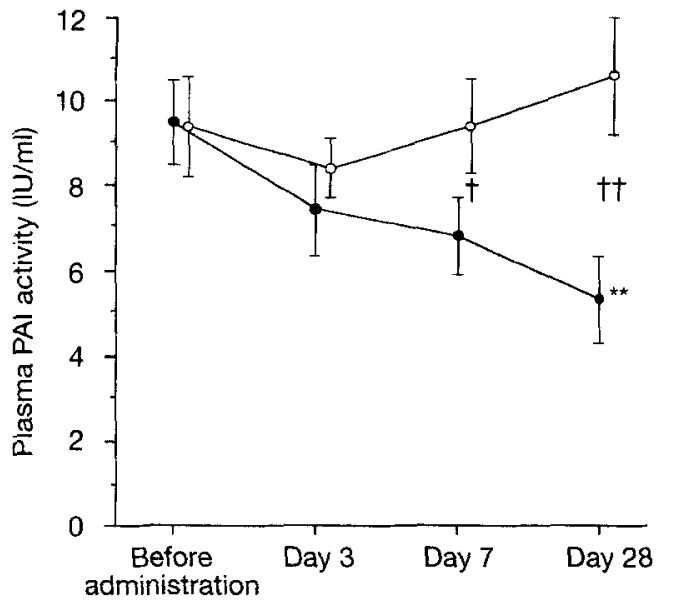

FIG. 2 Serial changes of the plasma plasminogen activator inhibitor (PAI) activity in the imidapril and placebo groups. $-=$ Imidapril, $-\sim=$ placebo. **p<0.01 vs. before administration, $\nmid \mathrm{p}<0.05 \mathrm{vs}$. placebo, $t+=p<0.01$ vs. placebo.

\section{Discussion}

Both the Studies of Left Ventricular Dysfunction (SOLVD) Prevention Trial and the Survival and Ventricular Enlargement (SAVE) Trial have revealed that ACE inhibition reduced the risk of acute coronary syndrome in patients after myocardial infarction. ${ }^{4,5}$ The decrease of PAI was associated with a reduced incidence of reinfarction. ${ }^{9,}{ }^{10}$ The plasma PAI-1 activity, after 4 weeks treatment with an ACE inhibitor, has been also shown to be lower than that before the treatment. ${ }^{12}$ In the present study, the fibrinolytic variables (plasma PAI activity, plasma PAl-1 antigen level, plasma TPA antigen level), and serum ACE activity were examined at four sampling points to compare the effects of imidapril on endogenous fibrinolysis with

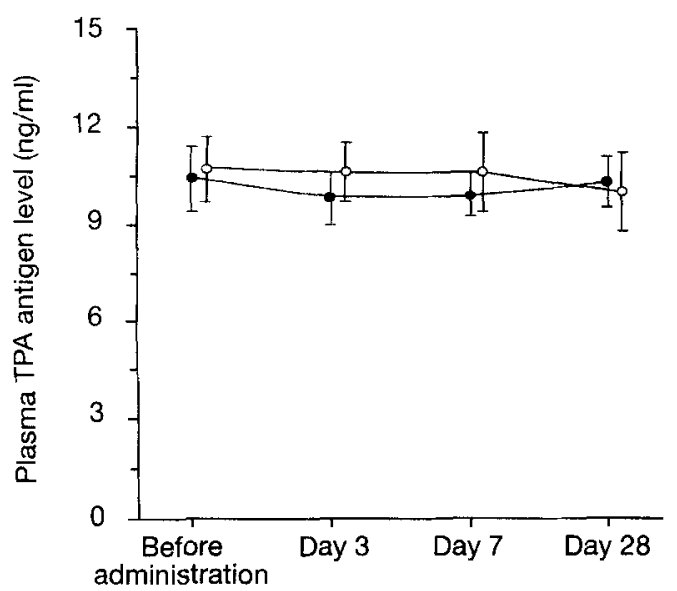

FIG. 4 Serial changes of the plasma tissue type plasminogen activator (TPA) antigen levels in the imidapril and placebo groups. - = Imidapril, $-\mathrm{O}=$ = placebo.

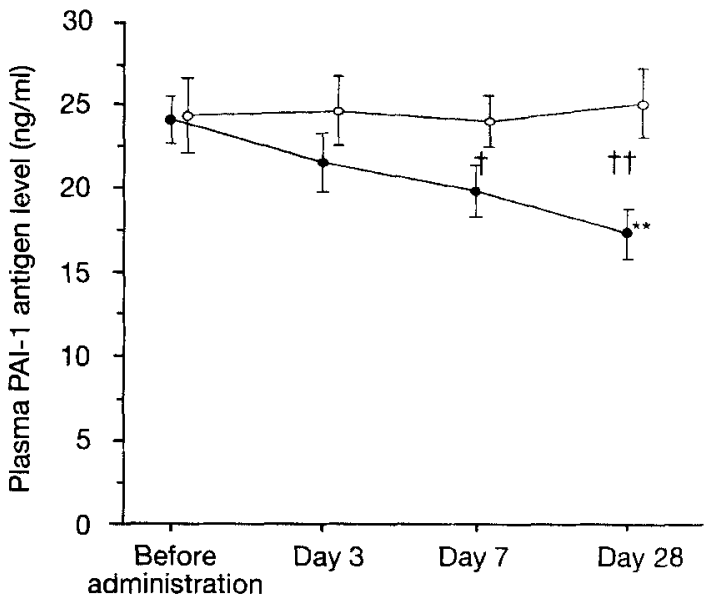

FIG. 3 Serial changes of the plasma plasminogen activator inhibitor type 1 (PAI-1) antigen levels in the imidapril and placebo groups. $-=$ Imidapril, $-\mathrm{O}-=$ placebo. $* * p<0.01$ vs. before administration, $\uparrow \mathrm{p}<0.05$ vs. placebo, $\uparrow \uparrow=p<0.01$ vs. placebo.

those on serum ACE activity. The serum ACE activity decreased significantly within 3 days after the start of imidapril administration, and the levels on Days 7 and 28 were also significantly lower. However, the plasma PAI activity and PAI- 1 antigen level were significantly lower on Days 7 and 28, but not on Day 3 after the start of administration, indicating that the decrease in plasma PAI after imidapril therapy occurs later than that in serum ACE activity. Recently, the expression of PAI-1 has been suggested to be mediated by angiotensin IV, which is a metabolite of angiotensin II. ${ }^{19} \mathrm{ACE}$ inhibitiors inhibit the conversion of angiotensin I to angiotensin II in the renin-angiotensin system, which results in a decrease of angiotensin II level. Furthermore, the decrease in angiotensin II leads to the reduction of angiotensin IV, which stimulates the expression of PAI-1. The residual angiotensin IV in the vascular tissue after administration of imidapril may be a cause of this time difference in the reduction in plasma PAI and serum ACE activity. At $5 \mathrm{mg} / \mathrm{kg} /$ day, imidapril is almost as potent as enalapril and more potent than captopril in inhibiting ACE activity in aorta, lungs, and brain tissue of spontaneously hypertensive rats after 10 weeks of oral treatment. ${ }^{13}$ The ACE activity in the aorta tissue 9 days after imidapril treatment was still at the reduced level, whereas that after treatment with enalapril and captopril almost returned to the control level. Therefore, the time difference may also be caused by the delay in inhibition of vascular tissue ACE caused by the slow tissue penetration and tissue washout of imidapril.

Recently, ACE has been shown to play a dual role. It is responsible for converting angiotensin I to angiotensin II in the renin-angiotensin system and for the degradation of bradykinin to inactive by-products in the kinin pathway. ${ }^{20}$ By activation of ACE, the angiotensin II level is increased and the bradykinin level is decreased. Conversely, by ACE inhibition, the angiotensin II level is decreased and bradykinin concentration is increased. Bradykinin has been suggested to stimulate 
the release of the plasminogen activator. ${ }^{21}$ However, in our study, the TPA antigen level did not change after imidapril administration, probably because imidapril has weaker activity to inhibit bradykinin hydrolysis by ACE than enalapril. ${ }^{22}$

In this randomized, placebo-controlled study, the fibrinolytic variables and ACE activity were examined at four sampling points. Serum ACE activity was decreased more rapidly than the plasma levels of PAI activity and PAI- 1 antigen in patients receiving imidapril.

\section{References}

1. Zamarron C, Lijnen HR, Collen D: Kinetics of the activation of plasminogen by natural and recombinant tissue-type plasminogen activator. J Biol Chem 1984;259:2080-2083

2. Chmielewska J, Ranby M, Wiman B: Evidence for a rapid inhibitor to tissue plasminogen activator in plasma. Thromb Res 1983;31: $427-436$

3. Urano T, Sakakibara K, Andrzej R, Urano S, Takada Y, Takada A: Relationships between euglobulin clot lysis time and the plasma levels of tissue plasminogen activator and plasminogen activator inhibitor 1. Thromb Haemost 1990;63:82-86

4. Pfeffer MA, Braunwald E, Moye LA, Basta L, Brown EJ, Cuddy TE, Davis BR, Geltman EM, Goldman S, Flaker GC, Klein M, Lamas GA, Packer M, Rouleau J, Rouleau JL, Rutherford J, Wertheimer JH, Hawkins CM: Effect of captopril on mortality and morbidity in patients with left ventricular dysfunction after myocardial infarction. N Engl J Med 1992;327:669-677

5. The SOLVD Investigators: Effect of enalapril on survival in patients with reduced left ventricular ejection fractions and congestive heart failure. N Engl J Med 1991;325:292-302

6. Sakamoto T, Yasue H, Ogawa H, Misumi I, Masuda T: Association of patency of the infarct-related coronary artery with plasma levels of plasminogen activator inhibitor activity in acute myocardial infarction. Am J Cardiol 1992;70:271-276

7. Masuda T, Yasue H, Ogawa H, Misumi I, Sakamoto T, Okubo H, Miyao Y, Kato H: Plasma plasminogen activator inhibitor activity and tissue plasminogen activator levels in patients with unstable angina and those with coronary spastic angina. Am Heart J 1992; 124:314-319

8. Hamsten A, Wiman B, Defaire U, Blombaeck M: Increased plasma level of a rapid inhibitor of tissue plasminogen activator in young survivors of myocardial infarction. $N$ Engl J Med 1985;313: $1557-1563$

9. Gram J, Jespersen J: A selective depression of tissue plasminogen activator ( $\mathrm{t}-\mathrm{PA}$ ) activity in euglobulin characterizes a risk group among survivors of acute myocardial infarction. Thromb Haemost $1987 ; 57: 137-139$
10. Hamsten A, De Faire U, Walldius G, Dahlen G, Szamosi A. Landou C, Blomback M, Wiman B: Plasminogen activattor inhibitor in plasma: Risk factor for recurrent myocardial infarction. Lancet 1987;2:3-9

11. Ridker PM, Gabouly CL, Comlin PR, Seely EW, Williams GH, Vaughan DE: Stimulation of plasminogen activator inhibitor in vivo by infusion of angiotensin II: Evidence of a potential interaction between the renin-angiotensin system and fibrinolytic function. Circulation 1993;87:1969-1973

12. Wright RA, Flapan AD, Alberti KGM, Ludlam CA, Fox KAA: Effects of captopril therapy on endogenous fibrinolysis in men with recent, uncomplicated myocardial infarction. $J$ Am Coll Cardiol 1994;24:67-73

13. Kubo M, Ochiai T, Kato J, Ishida R: Pharmacological studies on TA-6366, a new ACE inhibitor: II. Effect of long-term administration from the pre-hypertensive stage on blood pressure, relative heart weight and $\mathrm{ACE}$ activity of various tissues in spontaneously hypertensive rats (SHRs). Jpn J Pharmacol 1991;57:517-526

14. Masuda T, Ogawa H, Miyao Y, Yu Q, Misumi I, Sakamoto T, Okubo H, Okumura K, Yasue H: Circadian variation in fibrinolytic activity in patients with variant angina. Br Heart $J$ 1994;71: 156-161

15. Kasahara Y, Ashihara Y: Colorimetry of angiotensin-I converting enzyme activity in serum. Clin Chem 1981;27:1922-1925

16. Eriksson E, Ranby M, Gyzander E, Risberg B: Determination of plasminogen activator inhibitor in plasma using t-PA and a chromogenic single-point poly-D-lysine stimulated assay. Thromb Res 1988;50:91-101

17. Declerck PJ, Alessi MC, Verstreken M, Kruithof EKO, Vague IJ, Collen D: Measurement of plasminogen activator inhibitor 1 in biological fluids with a murine monoclonal antibody-based enzymelinked immunosorbent assay. Blood 1988;71:220-225

18. Holvoet P, Cleemput H, Collen D: Assay of human tissue-type plasminogen activator ( $t$-PA) with an enzyme-linked immunosorbent assay (ELISA) based on three murine monoclonal antibodies to t-PA. Thromb Haemost 1985;54:684-687

19. Kerins DM, Hao Q, Vaughan DE: Angiotensin induction of PAI-1 expression in endothelial cells is mediated by the hexapeptide angiotensin IV. J Clin Invest 1995;96;2515-2520

20. Johnston CI, Clappison BH, Anderson WP, Yasujima M: Effect of angiotensin converting enzyme inhibition on circulating and local kinin levels. Am J Cardiol 1982;49:1401-14(44

21. Brown NJ, Nadeau J, Vaughan DE. Bradykinin increases tissue plasminogen activator in humans (abstr). Cirulation 1995;92 (suppl I):I-36

22. Okamura T, Kitamura Y, Kimura T, Toda N: Comparison of selective actions of imidaprilat and enalaprilat on the response to angiotensin I and bradykinin in isolated dog blood vessels. $O$ yo Yakuri/Pharmacometrics 1993;46:427-436 